\title{
Marketing Efficiency of Organic Rice in Lampung Province
}

\author{
Muhammad Irfan Affandi ${ }^{1, *}$, Sri Handayani ${ }^{1}$ \\ ${ }^{I}$ Department of Agribusiness, Lampung University, Bandar Lampung, Indonesia, \\ *Corresponding author. Email: irfanaffandi58@gmail.com
}

\begin{abstract}
The problems that often occur in marketing organic rice is marketing channels have not been efficient. The purpose in this research was to identify the marketing channels of organic rice and analyze marketing efficiency of organic rice in Lampung Province. The location of the study was conducted purposive in organic rice producing districts, namely Pringsewu and South Lampung Regency. The research method uses descriptive methods. Data analysis uses qualitative and quantitative analysis (marketing margin and farmer's share). Total respondents were 20 producer farmers, farmer groups, 2 village collecting traders, and 1 retailer. The results showed that there were 3 types of marketing channels, namely channel I (farmers - traders consumers), channel II (farmers - farmer groups - retail - consumers), and channel III (farmers - tengkulak consumers). In terms of the economics of marketing channels organic rice II is more efficient than marketing channels I and III. The market channel II has the highest farmer's share value of $80.95 \%$ with the lowest margin of IDR.4,000 per kg.
\end{abstract}

Keywords: marketing channels, organic rice, marketing efficiency

\section{INTRODUCTION}

Demand for organic products in the world is increasing as the community develops a healthy lifestyle [1]. The demand for healthy food in Indonesia can be the basis for developing organic agriculture. In Indonesia, organic agriculture is applied to various food, horticultural and plantation commodities. In addition to healthy and safe consumption of long-term organic agricultural products, the production process of organic agriculture does not damage the environment. The advantage of this technology is to minimize or even completely eliminate pesticide residues and other hazardous chemicals [2].

Lampung Province is one of the national rice barns outside Java which has always experienced an increase in production. According to [3], rice production in Lampung Province reached 3,320,064 tons, planted area of 648,731 hectares and productivity levels reached 4.2 tons/ha. The potential for developing organic rice is very high, seeing the rice planting area reaches 23,611 hectares and 88,129 hectares in each Regency can be expanded with various agricultural extensification programs. In addition, the demand for organic rice in Indonesia reaches 1.1 quintals and this should be an opportunity besides the higher selling price of organic rice [4].

The development of organic rice farming in Lampung Province has constraints such as limited production capital, no policy on selling prices of farmers, tengkulak still play a role due to family economic pressure, and limited information on organic rice markets [1]. The limited capital experienced by farmers includes capital production and narrow land ownership, on average farmers in Lampung Province have a land area of less than 0.5 hectares. Seasonal nature of agricultural crops causes organic rice farmers to have income according to the harvest season. the yield of organic rice products must be immediately distributed to consumers because it has a perishable nature. Limitations of market information and marketing channels that are not yet clear because market conditions for organic rice to be marketed locally, some farmers sell organic rice at the price of ordinary/nonorganic rice, and sell to middlemen who make organic rice produced by farmers into organic rice products with regional trademarks other.

The marketing process plays an important role to support the distribution of production to consumers. Trading is the flow of delivery of goods and services from producers through various stages to consumers $[5,6]$. The purpose of trading is not only to deliver goods services to consumers but also to get profits through customer satisfaction [7]. The third system is efficient when supported by a series of organizations that are interdependent in moving goods/services. This series of organizations will bring goods/services moving from the producer to the consumer, called the marketing channel.

Marketing institutions involved in delivering agricultural goods and services to consumers play an important role in pricing. In terms of marketing organic products, the role of the issuing institution is very important, because it will create a new distribution channel for organic food products. Furthermore, to improve efficiency, a study of marketing systems is needed and the problems faced by each marketing agent in the marketing activities [8]. The purpose of this research is 1) identify the marketing 
channels of organic rice, 2) analyze the efficiency of marketing organic rice in Lampung Province.

\section{METHODS}

The research method used is descriptive research [9] states that descriptive methods are a method used to describe or analyze a research result but are not used to make broader conclusions. The study was conducted in the district of organic rice, namely Pringsewu Regency using method purposive, considering that the area has the largest organic rice planting area in Lampung Province and represents the upstream and downstream areas of organic agriculture.

\subsection{Method Sampling}

The Method of collecting data is through observation, surveys, in- depth interviews and focus group discussions, with respondents consisting of: organic rice farmers of 20 people using the proportional random sampling technique. Determination of marketing institutions using the snowball sampling method. The snowball method is a sample selection technique by first specifying one key information (key person), then selecting the next sample depends on the first informant, and so on until the information obtained has sufficient information needed [10]. Determination of the limits of the final level of marketing institutions is marketing institutions that sell organic rice to household / restaurant consumers in Pringsewu and South Lampung Regencies. In this study one village collector was found and 1 retailer was one person.

\subsection{Data Analysis Methods}

Marketing efficiency analysis is done by analyzing the performance of the organic rice market. Market performance is a performance that is seen due to the interaction between market structure (market structure) and market behavior (market conduct). The interaction between structure and market behavior tends to be complex and influence each other, so that market performance analysis in this study is approached through several indicators, namely:

1) Marketing channels

Marketing channels are analyzed qualitatively (descriptively) at each marketing institution involved in the process of flow of goods.

2) Farmer Share (Fs)

Farmer Share analysis aims to find out the price portion received by farmers (producers). If the Fs is higher, the market performance will be better from the producer side. Calculation of farmer's share is to determine the part of the price received by the farmer from the consumer prices level in units of percentage (\%). The formulation farmer's share is as follows [11]:
Fs $=\frac{P_{f}}{P_{r}} \times 100 \%$

Description:

Fs $=$ Farmer's share

$\mathrm{Pf}=$ Price at producer / farmer level (IDR/Kg)

$\mathrm{Pr}=$ Price at consumer level (IDR/Kg)

3) Marketing margin and ratio profit margin (RPM)

The marketing margin for organic rice is calculated the selling price and purchase price of each institution involved in marketing organic rice or the sum of the marketing costs incurred and profits obtained by marketing institutions. Mathematical marketing margins can be formulated as follows [5]:

$\mathrm{Mi}=\mathrm{Psi}-\mathrm{Pbi}$

$\mathrm{Mi}=\mathrm{Ci}+\pi \mathrm{i}$

$\mathrm{Psi}-\mathrm{Pbi}=\mathrm{Ci}+\pi \mathrm{i}$

The market institution margin of the i-level:

$\Pi \mathrm{i}=\mathrm{Psi}-\mathrm{Pbi}-\mathrm{Ci}$

The amount of total marketing margin is:

$\mathrm{MT}=\Sigma \mathrm{Mi}$

Description:

$\mathrm{Mi}=$ marketing margin in the market i-level

Psi $=$ i-level market selling price

$\mathrm{Pbi}=\mathrm{i}$-level market purchase price

$\mathrm{Ci}=\mathrm{i}$-marketing institution cost

$\Pi i=$ Benefits of marketing institutions

$\mathrm{MT}=$ total margin

$\mathrm{i}=1,2,3, \ldots . ., \mathrm{n}$.

\section{RESULTS AND DISCUSSION}

Marketing is important in distributing rice to consumers. The pattern of marketing in rice producing region in Indonesia is very diverse. However, the same thing is that farmers always act as prices taker [12], while price makers are more dominantly determined by traders of rice. For organic rice products, the selling price is generally higher than non-organic rice.

Marketing efficiency can be measured using market performance analysis. The efficiency of marketing organic rice reflects the spread of profit and benefits obtained by each of the actors marketing organic rice. In this study, the performance of the organic rice market was analyzed through marketing channel analysis, producer share, marketing margin and profit margin ratio, price correlation analysis and price transmission analysis.

\subsection{Marketing Channels}

The marketing channels for organic rice at the research location consist of:

1. Farmers $\rightarrow$ Collector Traders $\rightarrow$ Consumers

2. Farmers $\rightarrow$ Collector Traders (Farm Organic Partners)

$\rightarrow$ Retail $\rightarrow$ Consumers

3. Farmers $\rightarrow$ Tengkulak $\rightarrow$ Consumers 
On the first channel, farmers sell organic rice to collectors (Prosperous Groups). The selling price of organic rice is IDR 12,000. Collecting merchants repackaged organic rice products with their own packaging and sold at a price of IDR 18,000 to consumers. In the second channel, farmers sell their crops to farmer groups (Mitra Organik Farm) with farmer selling prices of IDR 17,000. Mitra Organik Farm repackage organic rice products and sell organic rice products to the Bandar Lampung region to retailers at a price of IDR 18,000. Furthermore, retailers sell products at a price of IDR 21,000 to consumers. In addition to channels 1 and 2, farmers also sell their crops on the third channel, which is selling products to tengkulak due to economic pressure. The selling price of rice is not an organic price, but the price of non-organic rice is IDR 7,000 . The total sales volume of organic rice for all farmer respondents is 17,570 kilograms. But those who managed to sell at organic prices were 4,550 kilograms (26\%), while the rest were sold on the third channel / non-organic prices totaling 13,020 kilograms (74\%).

\subsection{Marketing margin and profit margin ratio}

One of the indicators used to determine the efficiency of a marketing system is the marketing margin [13]. Marketing margin is the difference between the price at the producer level (Pf) and the price at the consumer level (Pr). Marketing margins have an important role in determining the size of producer income, because it directly affects the formation of organic rice prices at the producer level.

\subsubsection{Marketing margin analysis channel I}

At marketing channel I (farmers - collectors - consumers), organic rice farmers sell their crops directly to collectors at an average price of IDR 12,000 per kilogram. Farmers pay marketing costs including harvest costs (IDR 300), transportation costs (IDR 500 -), farmers' net profit of IDR 5,200 per kilogram. Thus, the share of producers in channel I was $66.67 \%$ (Table 1).

Table 1 Analysis of Marketing Margins of Organic Rice at Marketing Channels

\begin{tabular}{|l|l|r|l|l|}
\hline No & Market institution & $\begin{array}{l}\text { Price } \\
\text { (IDR) }\end{array}$ & $\begin{array}{l}\text { Share } \\
(\boldsymbol{\%})\end{array}$ & RPM \\
\hline 1 & Farmer & & & \\
\hline & Production cost & 6.000 & & \\
\hline & Harvest cost & 300 & & \\
\hline & Transportation & 500 & & \\
\hline & Selling Price & 12.000 & & \\
\hline & Profit & 5.200 & & \\
\hline 2 & Trader & & & \\
\hline & Purchase price & 12.000 & & \\
\hline & - Packing & 300 & & \\
\hline & - Telephone & 700 & & \\
\hline & - Sortation & 200 & & \\
\hline
\end{tabular}

\begin{tabular}{|l|l|r|l|l|}
\hline No & Market institution & $\begin{array}{l}\text { Price } \\
(\text { IDR })\end{array}$ & $\begin{array}{l}\text { Share } \\
(\boldsymbol{\%})\end{array}$ & RPM \\
\hline & Total cost & 13.200 & & \\
\hline & Selling Price & 18.000 & & \\
\hline & Profit & 4.800 & & 4 \\
\hline 3 & Marketing margin & 6.000 & & \\
\hline & $\begin{array}{l}\text { Consumer purchase } \\
\text { price }\end{array}$ & 18.000 & 100 & \\
\hline & Total profit & 10.000 & & \\
\hline & total marketing costs & 2.000 & & \\
\hline & $\begin{array}{l}\text { Total marketing } \\
\text { margin }\end{array}$ & 6.000 & & \\
\hline & Farmer share & & 66,67 & \\
\hline
\end{tabular}

Table 1 shows that marketing margins obtained by traders the collector is IDR 6,000 per $\mathrm{kg}$ with a ratio of profit margin of 4 , this means that every IDR 1,000 issued by the collector will bring a profit of IDR 4,000.

\subsubsection{Marketing margin analysis channel II}

On marketing channel II (Farmers - Collector Traders (Organic Farm Partners) - Retail - Consumers), organic rice farmers sell their crops directly to farmers (Mitra Organik Farm) with an average price of IDR 17,000 per kilogram. Farmers pay the cost of IDR 7,000 organic rice farming, and marketing includes harvest costs (IDR 300), transportation (IDR400), sorting costs IDR 300, so net profit farmers' is IDR 9,000 per kilogram. Producers share on channel II is $80.95 \%$ (Table 2).

Table 2 Analysis of Marketing Margins of Organic Rice at Marketing Channel II

\begin{tabular}{|l|l|r|l|l|}
\hline No & Market institution & $\begin{array}{l}\text { Price } \\
\text { (IDR) }\end{array}$ & $\begin{array}{l}\text { Share } \\
(\%)\end{array}$ & RPM \\
\hline 1 & Farmer & & & \\
\hline & Production cost & 7.000 & & \\
\hline & Harvest cost & 300 & & \\
\hline & Transportation & 400 & & \\
\hline & Sorting cost & 300 & & \\
\hline & Total cost & 8.000 & & \\
\hline & Selling price & 17.000 & & \\
\hline & Profit & 9.000 & & \\
\hline $\mathbf{2}$ & PP (Mitra Organik) & & & \\
\hline & Purchase price & 17.000 & & \\
\hline & - Packaging cost & 200 & & \\
\hline & - Telephone cost & 400 & & \\
\hline & Total cost & 17.600 & & \\
\hline & Selling price & 18.000 & & \\
\hline & Profit & 400 & & 0,67 \\
\hline & Marjin pemasaran & 1.000 & & \\
\hline $\mathbf{3}$ & Retail (Modern & & & \\
& market) & & & \\
\hline & Purchase price & 18.000 & & \\
\hline & Marketing cost & 500 & & \\
\hline & Selling price & 21.000 & & \\
\hline
\end{tabular}




\begin{tabular}{|l|l|r|l|l|}
\hline No & Market institution & $\begin{array}{l}\text { Price } \\
(\text { IDR })\end{array}$ & $\begin{array}{l}\text { Share } \\
(\boldsymbol{\%})\end{array}$ & RPM \\
\hline & Profit & 2.500 & & 5 \\
\hline $\mathbf{4}$ & Margin & 3.000 & & \\
\hline & $\begin{array}{l}\text { Consumer purchase } \\
\text { price }\end{array}$ & 21.000 & 100 & \\
\hline & Total profit & 11.900 & & \\
\hline & total marketing costs & 1.600 & & \\
\hline & $\begin{array}{l}\text { Total marketing } \\
\text { margin }\end{array}$ & 4.000 & & \\
\hline & Farmer share & & 80,95 & \\
\hline
\end{tabular}

Table 2 shows that the marketing margin obtained by collector traders (Organic Farmer Group) is IDR 1,000 per $\mathrm{kg}$ with a ratio of profit margin of 0.67 , this means that every IDR 1,000 issued by the collector will bring him a profit of IDR 670. While at the retail level, the marketing margin obtained is IDR 3,000 per $\mathrm{kg}$ with a value of the profit margin ratio of 5, this means that every IDR 1,000, which is issued by retailers, will get a profit IDR 5,000.

\subsubsection{Marketing margin analysis Channel III}

In marketing channel III (farmers - tengkulak - consumer), organic rice farmers sell their crops to tengkulak at a nonorganic price of IDR 7,000 per kilogram. Farmers do not cover marketing costs, because those who harvest rice and transportation will pay by tengkulak. Tengkulak buys organic rice at a low price because it will resell organic rice using another regional trademark with a selling price of IDR 15,000 . Then, the share of producers in channel III is $46.67 \%$ (Table 3 ).

Table 3 Analysis of Marketing Margins of Organic Rice at Marketing Channel III

\begin{tabular}{|c|c|c|c|c|}
\hline No & Market institution & $\begin{array}{l}\text { Price } \\
\text { (IDR) }\end{array}$ & $\begin{array}{l}\text { Share } \\
(\%)\end{array}$ & RPM \\
\hline \multirow[t]{4}{*}{1} & Farmer & & & \\
\hline & Production cost & 6.000 & & \\
\hline & Selling price & 7.000 & & \\
\hline & Profit & 1.000 & & \\
\hline \multirow[t]{9}{*}{2} & Tengkulak & & & \\
\hline & Purchase price & 7.000 & & \\
\hline & - Packaging cost & 200 & & \\
\hline & - Telephone cost & 500 & & \\
\hline & - Transportation & 500 & & \\
\hline & Total cost & 8.200 & & \\
\hline & Selling price & 15.000 & & \\
\hline & Profit & 6.800 & & 5,67 \\
\hline & Margin & 8.000 & & \\
\hline \multirow[t]{5}{*}{3} & $\begin{array}{l}\text { Consumer purchase } \\
\text { price }\end{array}$ & 15.000 & 100 & \\
\hline & Total profit & 7.800 & & \\
\hline & total marketing costs & 1.200 & & \\
\hline & $\begin{array}{l}\text { Total marketing } \\
\text { margin }\end{array}$ & 8.000 & & \\
\hline & Farmer share & & 46,67 & \\
\hline
\end{tabular}

Table 3 shows that the marketing margin obtained by tengkulak is IDR 8,000 per $\mathrm{kg}$ with a ratio of profit margin of 5.66, this means that every IDR 1,000 issued by the collector will bring him a profit of IDR 5,660.

\subsection{Marketing Efficiency}

The criteria used to know that marketing organic rice is economically efficient are from the share of producers. If the portion received by the farmer is less than $50 \%$, it means that it is not efficient and if the portion received by the farmer is more than $50 \%$ then the marketing is efficient. The lower the marketing margin means the part that is received will be greater and the higher the marketing margin means that the portion received by farmers will be smaller [14]. The farmer's share in marketing channel I is $66.67 \%$, the marketing channel II farmer's share is $80.95 \%$, and the channel III farmer's share is $46.67 \%$. (Table 4 ).

Table 4 Share of Producers Marketing Channel Organic Rice at the Research Location

\begin{tabular}{|l|l|l|l|}
\hline $\begin{array}{l}\text { Marketing } \\
\text { chanel }\end{array}$ & $\begin{array}{l}\text { Pf } \\
\text { (Rp) }\end{array}$ & $\begin{array}{l}\text { Pr } \\
(\mathbf{R p})\end{array}$ & $\begin{array}{l}\text { Fs } \\
(\mathbf{\%})\end{array}$ \\
\hline Chanel I & 12.000 & 18.000 & 66,67 \\
\hline Chanel II & 17.000 & 21.000 & 80,95 \\
\hline Chanel III & 7.000 & 15.000 & 46,67 \\
\hline
\end{tabular}

Marketing channel II gives the highest share for farmers, which is $80.95 \%$, because farmers 'selling prices are higher and the role of farmer groups in accommodating farmers' harvests. The farmer group Mitra Organik Farm also plays a role in finding retailers in the Bandar Lampung region. Collaboration with retailers is the key to successful sales on channel II. The results of the research abaut supply chain of organic rice by [15] support the conclusion of this study, so that organic rice marketing is efficient, there needs to be an effort to improve through discipline delivery regulation, product quality improvement, and cost efficiency to improve marketing efficiency.

\section{CONCLUSION}

The results of the analysis showed that the organic rice of the Mentik susu gave higher added value compared to inorganic rice of the Sintanur 2,912 and 1,200 with an added value ratio of 0.28 and 0.15 , respectively. The value of profits obtained by organic rice Mentik susu and Sintanur is $\mathrm{Rp} 2,193.75$ and 505.56 with a profit ratio of 0.75 and 0.42 , respectively. While inorganic rice had added value 675 with added value ratio 0.14 . The value of profits obtained by inorganic is Rp320.8 with a profit ratio of 0.48 . This shows that organic rice Mentik susu provide more added value than Sintanur and inorganic rice (Ciherang). 


\section{REFERENCES}

[1] S. Handayani, \& M.I. Affandi. 2019. Supply Chain Management Performance Of Organic Rice In Pringsewu Regency. In Journal of International Conference Proceedings (Vol. 2, No. 1).

[2] S. Handayani. 2016. Analisis Keuntungan Dan Sensitivitas UMKM Makanan Ringan Berbahan Baku Singkong Di Kecamatan Gedong Tataan”. Prosiding Seminar Nasional Teknologi Pertanian. 2016.

[3] Badan Pusat Statistik. 2015. Planting, Data Rice Production and Productivity. http://bps.go.id.Accessed on September 4, 2015.

[4] Sulaeman, Ahmad. 2009. Produk Pertanian Organik Di Indonesia Dari Produsen Hingga Pemasaran. Simposium ISSAAS Indonesian Chapter. Bogor.

[5] Kohls, R.L. Dan J.N. Uhl. 2002. Marketing Of Agricultural Products. Ninth Edition. Macmillan Company. New York.

[6] Yuniarti, D., Rahayu, E. S., \& Harisudin, M. (2018). Saluran Pemasaran Beras Organik di Kabupaten Boyolali. Agrisocionomics: Jurnal Sosial Ekonomi Pertanian, 1(2).

[7] Mursid. 2014. Marketing Management. Bumi Aksara. Jakarta.

[8] M. Arbi, T. Thirtawati, \& Y. Junaidi. 2018. Channel Analysis and Marketing Efficiency Levels of Semi Organic Rice in Rambutan District, Banyuasin Regency. JSEP (Journal of Social And Agricultural Economics), 11(1), 22-32.

[9] Sugiyono. 2005. Understanding Qualitative Research. CV. Alfabeta. Bandung.

[10] H. Irianto, and T. Mardikanto. 2011. Methods Agribusiness Research and Evaluation. Agribusiness Department / Study Program, Faculty of Agriculture, UNS.

[11] B. Swastha and I. Sukotjo. 2002. Pengantar Bisnis Modern. Edisi Keenam. Liberty. Yogyakarta

[12] S. Handayani, N. Anggraini, \& C. Yolandika. 2019. Efisiensi Usahatani Padi Organik di Kecamatan Candipuro. In Prosiding Seminar Nasional Teknologi Pertanian (Vol. 2018).
[13] A.I. Hasyim. 2003. Agricultural Trade Administration (Diktat Kuliah). Faculty of Agriculture, University of Lampung. Bandar Lampung.

[14] Darmawati, Khomsiyah, and Rahayu. 2005. Relationship between Corporate Governance and Company Performance. Indonesian Accounting Research Journal.

[15] Handayani, S., Affandi, M. I., \& Irawati, L. 2019. Identifying Supply Chain Performance of Organic Rice in Lampung. International Journal of Applied Business and International Management, 4(2), 4148. 